on agriculture and gardening. All the religions of the region are met with among them. Around $\mathrm{He}$-cheu they are all Mussulmans; but families having several male children send one of them to a Lamaite monastery so as not to divide their landholdings too greatly, and so a class of Buddhist Lamas has arisen. Those who have received Chinese instruction follow the teachings of Confucius, while the remainder go indifferently to Buddhist or Chinese temples, and many have Shamanist divinities. As to M. Berezovsky, he has left the expedition and has taken another route, via Hoy-syan; he proposes to rejoin MM. Potanin and Skassi on their way to the south.

THE expedition which is reported to have been massacred in New Guinea was sent out by the Geographical Society of Aus tralasia, founded in May I883. The commander, Capt. Henry Charles Everill, had been selected from a number of candidates, and his staff included a naturalist, a surgeon, two sub-leaders, one on land and the other on sea, a photographer, three natura history collectors, a surveyor, an engineer, and a "general utility" volunteer. Very full instructions were drawn out for the expedition, while considerable discretion was left to the leader to adapt his operations to circumstances. The instructions included directions not only for surveying work, but for observations on the natives, on zoology, botany, and geology, with directions for the collection and preservation of specimens. The expedition was to enter the Aird River, which is probably only an east arm of the Fly River. As a matter of fact, a telegram of September 22 announced the arrival of the Bonito (the vessel in which the expedition sailed from Sydney) in the Fly River. It was to penetrate as far as possible into the interior. The Australasian Society contributed $500 \%$. to the expedition of Mr. H. O. Forbes, who, according to latest news, was at Port Moresby preparing to penetrate into the interior. Happily the report of the massacre is discredited by the British resident on Thursday Island.

THE Geographical Society of Lisbon passed a resolution at its last meeting asking the Portuguese Government to make a money grant by way of remuneration to the explorers MM. Capello and Ivens, and to pay the cost of publishing not less than 5000 copies of the account of their journey. It was also resolved to address every commercial association throughout the country pointing out the necessity of establishing a company or society for the purpose of investigating colonial markets hitherto imperfectly known, but of which MM. Capello and Ivens are showing the importance.

AT the last meeting of the Paris Society of Commercial Geo graphy on the 2oth ult., the Burmese Envoy being present, M. Bran de Saint Pol Lias described his recent journeys in IndoChina, which appear not to have extended far beyond Saigon, Cambodia, and the delta of the Red River. Indeed, travel even in these comparatively frequented parts of the peninsula must have been difficult when the traveller was there, for the greater part of Tonquin and Cambodia was in rebellion at the time of his visit.

THE Bulle'in (2e trimestre, 1885 ) of the Paris Geographical Society, just published, contains a long report on the labours of the society, and on the progress of the geographical sciences, by M. Maunoir, the secretary. The work is, as usual, well and thoroughly done. The only other paper in the number is a description of the regions of Algeria traversed by the meridian of Paris, by Commander Derrien. This is accompanied by a map, and describes in succession, and with great detail, their orography, hydrography, geology, military roads, meteorology, military and administrative divisions, and also discusses the origin of the tribes of the Jebel Amour.

THE Geographical Society of Tokio appears to be steadily pursuing its work. The recent numbers of its fournal, which we have before us, show much activity in regions around Japan. Amongst the papers in the sixth volume we notice the follow ing :- The five races of the Chinese Empire, and their ancient progress, by Mr. Otori ; the interior of Northern Corea, by Mr. Kaizu ; travels in Siam; notes on Thibet (compiled from European sources) ; Formosa under the Chinese ; Manchuria : recent events in Annam; travels in South-eastern Russia; the salt-tax in China ; colonisation in Saghalien (a review); Formosa during the Dutch occupation; historical notes on the relations between Russia and China; notes on the aboriginal language of Formosa, with a considerable vocabulary; Candahar and the Lowe Cabul Valley, with a sketch map; the mines of Central Japan, with a map, and various other minor communications. The first number of the tenth volume contains a paper by $\mathrm{Mr}$. Akamatsu on the origin and condition of the Chinese emigrants to the Philippines, based apparently on the writings of Prof. Blumentritt on the subject; and one on the longitude of Japan, hy Mr. Arai, the head of the meteorological bureau. The fournal is printed in Japanese, but a short table of contents is appended in Enjlish.

THE leading paper in the current number (Heft 3 , Band viii.) of the Deutsche Geographisclie Blitter, the r rgan of the Geographical Society of Bremen, is one by Leonard Steineger, describing a voyage around Behring Island, off the coast of Kamchatka, in the autumn of I882. It describes at some length the incidents of the voyage, the capabilities of the island, \&c. The writer visited and describes the ruins of the hut in which Behring and his companions wintered I4I years previously, and where the traveller himself died, and was buried. Dr. von Steiner compiles from Mr. Im Thurn, an account of the Indians of Guiana. The usual geographical news concludes the number.

Mr. ScotT, of the Indian Survey Department, recently delivered a lecture at Calcutta on the transfrontier surveys of India, in which he pointed out that 20,000 square miles on the immediate north-westem frontier needed exploration. Here lie the Kafîla routes into Afghanistan, which he much regretted had not been used for the advance into Afghanistan instead of the hot and thirsty Bolan Pass. He suggested that the rules against British officers crossing the frontier should be relaxed, and that they should be permitted to accept invitations, with a guarantee of safety, by native officers to their home; across the border.

THE deaih of Col. Obigado, of the Argentine Army, on September 22 at Buenos Ayres is announced. In recent years he had made many scientific explorations on the coasts and in the interior of Patagonia. He traversed the forests in the basins of the Negro, Limay, and Nanquen rivers, which had never been explored before; and several places in these regions now bear his name. His death was clue to ill-health, caused by his journeys in Patagonia.

THE last issue of the Mittheilungen of the Geographical Society of Vienna contains two papers on the Carolines; one by Prof. Blumentritt describing the historical relations of Spain to the archipelago. He makes more interesting quotations from books used in Spanish schools, in which the Carolines are mentioned amongst the colonies of Spain, and the usual elementary school-book information is given about them. The secretary to the Society also gives a map of the group, with much geographical and other information respecting them. Herr Juilg concludes his paper on the erosive action of the sea, and the usual current geographical information brings the number (Band xxviii., No. IO) to a conclusion.

THE SCOTTISH METEOROLOGICAL SOCIETY

$\mathrm{A}^{\mathrm{T}}$ a meeting of the Directors of the Ben Nevis Observatory held on October 30 , it was intimated that during the summer Prof. Ewing, of Dundee, had visited the Observatory to make arrangements for the observations on earthquakes and earth movements which it had been resolved to carry on there. Prof. Vernon Harcourt and Mr. Harold Dickson, both of Oxford, also spent some time at the Observatory conducting experiments and observations on the intensity of light in flames, it being necessary, in connection with the important practical question of a satisfactory determination of the light-giving qualities of coal gas supplied to the public, to make experiments on such a situation as Ben Nevis, where barometric pressure is low. $\mathrm{Mr}, \mathrm{H} . \mathrm{N}$. Dickson resided two months at the Observatory, being chiefly engaged in carrying out, under the superintendence of Prof. Tait and Mr. Buchan, a valuable series of observations and experiments on the methods of observing the temperature and humidity of the air. For this purpose the season was a singularly suitable one, on account of the extremes of temperatures and humidities the weather presented during the summer on the Ben. As regards the humidity, where there were of course abundant opportunities of studying the behaviour of the instruments in an atmosphere completely saturated through a wide range of temperature, many cases occurred of excessive and protracted dryness of the atmosphere. On one occasion, in September, no deposition of dew took place on 
Prof. Chrystal's condensation hygrometer, though its temperature was lowered to $9^{\circ} \mathrm{o}$. These quite exceptional arid states of the air on Ben Nevis during the past summer are of the greatest interest, especially in their relations to the unprecedentedly severe early frosts which were so destructive to the potato and cereal crops over extensive breadths of the country during September. It was reported that since the middle of August subscriptions to the amount of about $300 \mathrm{l}$. had been already received from the original subscribers, and it was resolved to make the claims of the Observatory more widely known. At the same meeting the Council resolved that the discussion of the ob ervations of the temperature of the sea round Scotland be undertaken by the Scottish Marine Station at Granton chiefly with the view of constructing isothermal maps of the sea for each month round the Scottish coasts. The Secretary reported that he had during the summer inspected twenty-six of the Society's stations. The Duke of Buccleuch, and Messrs. Donald Beith, W.S.; Robert Irvine of Royston; B. N. Peach, Geological Survey ; and John Horn, also of the Geological Survey, were elected members of the Society.

\section{ON THE INTELLIGENCE OF THE DOG}

THE man and the dug have lived together in more or less intimate association for many thousands of years, and yet it must be confessed that they know comparatively little of one another. That the dog is a loyal, true, and affectionate friend must be gratefully admitted, but when we come to consider the psychical nature of the animal, the limits of our knowledge are almost immediately reached. I have elsewhere suggested that this arises very much from the fact that hitherto we have tried to teach animals, rather than to learn from them-to convey our ideas to them, rather than to devise any language or code of signals by means of which they might communicate theirs to us. The former may be more important from a utilitarian point of view, though even this is questionable, but psychologically it is far less interesting. Under these circumstances it occurred to me whether some such system as that followed with deaf mutes, and especially by Dr. Howe with Laura Bridgman, might not prove very instructive if adapted to the case of dogs. I have tried this in a small way with a black poodle named "Van." I took two pieces of cardboard about ro inches by 3 , and on one of them printed in large letters the word "food," leaving the other blank. I then placed two cards over two saucers, and in the one under the "food" card put a little bread and milk, which "Van," after having his attention called to the card, was allowed to eat. This was repeated over and over again till he had had enough. In about ten days he began to distinguish between the two cards. I then put them on the floor and made him bring them to me, which he did readily enough. When he brought the plain card I simply threw it back, while, when he brought the food card, I gave him a piece of bread, and in about a month he had pretty well learned to realise the difference. I then had some other cards printed with the words " out," "tea," "bone," "water," spelt phonetically, so as not to trouble him by our intricate spelling, and a certain number also with words to which I did not intend him to attach any significance, such as " nought," "plain," "ball," \&c. "Van" soon learned that bringing a card was a request, and soon learned to distinguish between the plain and printed cards; it took him longer to realise the difference between words, but he gradually got to recognise several, such as "food," "out," "bone," "tea," \&c. If he was asked whether he would like to go out for a walk, he would joyfully pick up the "out" card, choosing it from several others, and bring it to me, or run with it in evident triumph to the door. I need hardly say that the cards were not always put in the same places. They were varied quite indiscriminately and in a great variety of positions. Nor could the dog recognise them by scent. They were all alike, and all continually handled by us. Still I did not trust to that alone, but had a number printed for each word. When, for instance, he brought a card with "food" on it, we did not put down the same identical card, but another bearing the same word, when he had brought that a third, then a fourth, and so on. For a single meal, therefore, eighteen or twenty cards would be used, so that he evidently is not guided by scent. No one who has seen him look down a row of cards and pick up the one he wanted could, I think, doubt that in bringing a card he feels he is making a request, I Abstract of paper by Sir John Lubbock, Bart., M.P., F.R.S., read at
the Aberdeen meeting of the British Assjciation. and that he can not only distinguish one card from another, but also associate the word and the object. This is, of course, only a beginning, but it is, I venture to think, suggestive, and might be carried further, though the limited wants and aspirations of the animal constitute a great difficulty. My wife has a very beautiful and charming collie, "Patience," to which we are much attached. This dog was often in the room when "Van" brought the food card, and was rewarded with a piece of bread. She must have seen this thousands of times, and she begged in the usual manner, but never once did it occur to her to bring a card. She did not touch or indeed even take the slightest notice of them. I then tried the following experiment:-I prepared six cards about ro inches by three, and coloured in pairs-two yellow, two blue, and two orange. I put three of them on the floor, and then holding up one of the others, endeavoured to teach "Van" to bring me the duplicate. That is to say, that if the blue was held up, he should fetch the corresponding colour from the floor; if yellow, he should fetch the yellow, and so on. When he brought the wrong card he was made to drop it, and return for another till he brought the right one, when he was rewarded with a little food. The lessons were generally given by my assistant, Miss Wendland, and lasted half an hour, during which time he brought the right card on an average about twenty-five times. I certainly thought that he would soon have grasped what was expected of him. But no. We continued the lessons for nearly three months, but as a few days were missed, we may say for ten weeks, and yet at the end of the time I cannot say that "Van" appeared to have the least idea of what was expected of him. It seemed a matter of pure accident which card he brought. There is, I believe, no reason to doubt that dogs can distinguish colours; but as it was jus possible that "Van" might be colour blind, we then repeated the same experiment, only substituting for the coloured cards others marked respectively I., II., and III. This we continued for another three months, or, say, allowing for intermissions, ten weeks, but to my surprise entirely without success. I was rather disappointed at this, as, if it had succeeded, the plan would have opened out many interesting lines of inquiry. Still in such a case one ought not to wish for one result more than another, as of course the object of all such experiments is merely to elicit the truth, and our result in the present case, though negative, is very interesting. I do not, however, regard it as by any means conclusive, and should be glad to see it repeated. If the result proved to be the same, it would certainly imply very little power of combining even extremely simple ideas. I then endeavoured to get some insight into the arithmetical condition of the dog's mind. On this subject I have been able to find but little in any of the standard works on the intelligence of animals. Considering, however, the very limited powers of savage men in this respect-that no Australian language, for instance, contains numerals even up to four, no Australian being able to count his own fingers even on one hand-we cannot be surprised if other animals have made but little progress. Still, it is surprising that so little attention should have been directed to this subject. Leroy, who, though he expresses the opinion that "the nature of the soul of animals is unimportant," was an excellent observer, mentions a case in which a man was anxious to shoot a crow. "To deceive this suspicious bird, the plan was hit upon of sending two men to the watch-house, one of whom passed on, while the other remained; but the crow counted and kept her distance. The next day three went, and again she perceived that only two retired. In fine, it was found necessary to send five or six men to the watch-house to put her out in her calculation. The crow, thinking that this number of men had passed by, lost no time in returning." From this he inferred that crows could count up to four. Lichtenberg mentions a nightingale which was said to count up to three. Every day he gave it three mealworms, one at a time; when it had finished one it returned for another, but after the third it $\mathrm{kn}: \mathrm{w}$ that the feast was over. I do not find that any of the recent writers on the intelligence of animals, either Buchner, or Peitz, or Romanes, in either of his books, give any additional evidence on this part of the subject. There are, however, various scattered notices For instance, there is an amusing and suggestive remark in Mr. Galton's interesting " Narrative of an Explorer in Tropical South Africa." After describing the Damara's weakness in calculations, he says :-- "Once while I watched a Damara floundering hopelessly in a calculation on one side of me, I observed 'Dinah,' my spaniel, equally embarrassed on the other; she was overlooking half a dozen of her new-born puppies, 